\title{
Erratum, corrigenda et emendatio or "mistake, correction and amendment"
}

\author{
Marius M. Scarlat ${ }^{1}$
}

Published online: 10 May 2017

(C) SICOT aisbl 2017

Traditionally and in conformity with the ethics - when some information is missing from a paper already published - the authors or the Editor would write an "Erratum" adding the missing data or make the amendments to correct and to make the information reliable. The good use of science requires precision and clarity, our Journal publishes implicitly sometimes "Erratae". Corrections, corrigenda and partial retractions (such as for a single graph, statement, table or image) for previously-published articles are all recorded by the National Library of Medicine (NLM) as errata. (1) Our Journal published five Errata since January 2016 that is quite honorable for an annual volume of over 2400 pages and almost 400 papers but still too much in our critical and picky approach. As in this issue we publish two "Erratum" we wondered what bad mistakes would a show a paper to require correction or at least public acknowledgement.

A short journey in the Latin vocabulary shows that "erratum" means literally mistake or fault. Some other words from the same family include "lapsus", "emendatio" and "castigatio". Those two last words are more elegant as they include also the idea of reparation associated to the fault. The term "corrigenda" is also in use as a synonym with a meaning of "correction". The original Latin use of correction included also the word "discipline" as turbulent or irregular citizens in fault were severely "disciplined" by the Roman Power. Related English Words include "cut, deletion, addition, amplification, supplement, adjustment, alteration, modification, revision; improvement, renovation, clarification, explanation and explication. As outlined by the National Library of

Marius M. Scarlat

mscarlat@gmail.com

1 Clinique Chirurgicale St Michel, 83100 Toulon, France
Medicine "there is no differentiation between errors that originate in the publication process and those that result from errors of scientific logic or methodology, because journal editors do not make this distinction consistently or clearly. Corrections (corrigenda), and partial retractions for previously-published articles are all uniformly considered by NLM to be errata. Since 1987, the NLM added "errata" to the original cited article in order to alert users and provide link the source of the erratum information" [1].

In our records the errata [2] is a correction for an included reference in the article [3]. In the original article one citation has the wrong name of the first author.

The erratum [4] was related to a misspelling of one name of a co-author in the original publication [5], due to an oversight by the corresponding author in the correction process. We may comment with some bitterness that in many cases the corresponding author have probably the full mandate to eventually do the job on behalf of all the team and is "disciplined" or "corrected" too late, at the moment when the co-authors are finally reading the production in full, this is maybe funny but also somehow sad. We modified our submission process and we asked for a full confirmation from all the co-authors to avoid this type of error since more than one year now. Erratum [6] refers to disclosures and conflicts of interest in the original paper [7]. Those affiliations were missing from the original article and were brought by the Erratum. This was an amendment or addition as the mistake was incomplete information. One incorrect affiliation is seen also in erratum [8] and concerns the full address of the authors of the original paper [9].

The erratum [10] refers to a misspelling of a word in the title. Actually the spinal cord in the title was subject to "transection" that is quite more severe that the incorrectly published "transaction" [11]. The error was amended six years later! However, as you can easily observe or experience by yourselves, the Word spelling corrector from the computer will 
automatically correct "transection" to "transaction" because the first word belongs to the medical jargon and this traumatic event is very rare. The second word is from the vulgate or colloquial language.

Finally the Erratum [12] includes a precision concerning the authorship and the equal contribution of two authors to the work published. This amendment was published by author's request in their ceaseless combat to perfection...

It is our pleasure and pride to outline the quality of our technical team and the exceptional devotion and participation of Melbert Munieza, Annette Albrecht and Leah Mae Cabahug who are regularly checking all submitted pages, fighting with errors, misspellings, wrong affiliations, late submissions, incomplete or wrong abbreviations and also with the huge authors "egos" who are always in a hurry to get tenths of papers published per year (?!) and who often forget that behind a Journal are teams of devoted and hard working people who make things happen at a high turnover with celerity, facing short deadlines and finally presenting to the scientific community a publication of good academic level and very little errors that would need discipline;)

\section{References}

1. https://www.nlm.nih.gov/pubs/factsheets/errata.html - accessed April 28, 2017

2. Shaw KA, Dunoski BS, Mardis NJ, Pacicca DM. (2016) Erratum to: combined posterolateral corner and acute anterior cruciate ligament injuries in an adolescent cohort: a magnetic resonance imaging analysis. Int Orthop 2016 Mar;40(3):647. doi:10.1007/s00264-015-3094-y

3. Shaw KA, Dunoski BS, Mardis NJ, Pacicca DM (2016) Combined posterolateral corner and acute anterior cruciate ligament injuries in an adolescent cohort: a magnetic resonance imaging analysis. Int Orthop 2016 Mar;40(3):555-60. doi:10.1007/s00264-015-3026-x. Epub 2015 Nov 5. Erratum in: Int Orthop. 2016 Mar;40(3):647
4. Kutzner KP, Freitag T, Kovacevic MP, Pfeil D, Reichel H, Bieger R (2016) Erratum to: one-stage bilateral versus unilateral short-stem total hip arthroplasty: comparison of migration patterns using "Einbild-roentgen-analysis femoral-component-analysis". Int Orthop 2016 Oct;40(10):2209

5. Kutzner KP, Freitag T, Kovacevis MP, Pfeil D, Reichel H, Bieger R (2016) One-stage bilateral versus unilateral short-stem total hip arthroplasty: comparison of migration patterns using "Ein-bildroentgen-analysis femoral-component-analysis". Int Orthop 2017 Jan;41(1):61-66. doi:10.1007/s00264-016-3184-5

6. Jauregui JJ, Naziri Q, Pierce TP, Elmallah RK, Cherian JJ, Delanois RE, Mont MA (2016) Erratum to: is the use of thin, highly crosslinked polyethylene liners safe in total hip arthroplasty? Int Orthop 2016 Oct;40(10):2211. doi:10.1007/s00264-016-3238-8

7. Jauregui JJ, Naziri Q, Pierce TP, Elmallah RK, Cherian JJ, Delanois RE, Mont MA (2016) Is the use of thin, highly cross-linked polyethylene liners safe in total hip arthroplasty? Int Orthop 2016 Apr;40(4):681-686. doi: 10.1007/s00264-015-2841-4

8. Windisch C, Brodt S, Röhner E, Matziolis G (2017) Erratum to: effects of Kinesio taping compared to arterio-venous impulse system ${ }^{\mathrm{TM}}$ on limb swelling and skin temperature after total knee arthroplasty. Int Orthop. 2017 Apr;41(4):855. doi: 10.1007/s00264-017-3424-3

9. Windisch C, Brodt S, Röhner E, Matziolis G. (2017) Effects of Kinesio taping compared to arterio-venous impulse system ${ }^{\mathrm{TM}}$ on limb swelling and skin temperature after total knee arthroplasty. Int Orthop 2017 Feb;41(2):301-307. doi: 10.1007/s00264-016-3295-z

10. Chandrashekhara SH, Kumar A, Gamanagatti S, Kapoor K, Mukund A, Aggarwal D, Sinha S (2017) Erratum to: unusual traumatic spondyloptosis causing complete transection of spinal cord. Int Orthop 2017 Apr 6. doi:10.1007/s00264-017-3479-1

11. Chandrashekhara SH, Kumar A, Gamanagatti S, Kapoor K, Mukund A, Aggarwal D, Sinha S. (2011) Unusual traumatic spondyloptosis causing complete transaction of spinal cord. Int Orthop 2011 Nov;35(11):1671-1675. doi: 10.1007/s00264-010-1190-6

12. Ćuti T, Antunović M, Marijanović I, Ivković A, Vukasović A, Matić I, Pećina M, Hudetz D. (2017) Erratum to: capacity of muscle derived stem cells and pericytes to promote tendon graft integration and ligamentization following anterior cruciate ligament reconstruction. Int Orthop 2017 Apr 21. doi:10.1007/s00264-017-3488-0 